\title{
Lysine-Specific Demethylase 5A
}

National Cancer Institute

\section{Source}

National Cancer Institute. Lysine-Specific Demethylase 5A. NCI Thesaurus. Code C97597.

Lysine-specific demethylase 5A (1690 aa, 192 kDa) is encoded by the human KDM5A

gene. This protein plays a role in both histone demethylation and the positive regulation

of gene transcription. 